\title{
A CROSS-AGE COMPARISON OF SCIENCE STUDENT TEACHERS' CONCEPTUAL UNDERSTANDING OF SOIL EROSION
}

Sibel Er Nas, Muammer Çalık

Trabzon University, Turkey

E-mail: sibelernas@hotmail.com, muammer38@hotmail.com

\begin{abstract}
The relevant literature has shown that student teachers hold alternative conceptions of soil erosion. Even though Turkish science student teachers are expected to teach the concept of 'soil erosion' in lower secondary schools (grades 5-8), none of the earlier studies have explored their conceptual growth and/or mental models throughout a 4-year undergraduate program. Indeed, science (student) teachers, who play a pivotal role in teaching the sustainability of soil as an environmental heritage, are able to transfer their environmental knowledge and mental models to younger generations. Therefore, the aim of this research was to elicit science student teachers' (SSTS) understanding of soil erosion. In a cross-age comparison, the sample of the research was comprised of the first-year $(n=54)$, second-year $(n=62)$, third-year $(n=60)$, and fourth-year of a four-year science education program (n=65), a total of 241 SSTs, enrolled at the Department of Science Education in Karadeniz Technical University in Turkey. A questionnaire with 4 open-ended questions and semi-structured interviews were used to collect data. The results indicated that the majority of the SSTS confused the concept of 'soil erosion' with the one 'landslide'. For this reason, the current research suggests the development of analogies and computer simulations to overcome this confusion.
\end{abstract}

Keywords: conceptual understanding, cross-age, mental model, science student teacher, soil erosion.

\section{Introduction}

An increase in population growth and advances in science and technology have caused global changes in food production and energy use, climate, land use, air and water quality. Interactions between humans and their environment have triggered environmental degradation. Since the degradation of environmental resources brings about anthropogenic environmental problems (Bozkurt, Salman Akın, \& Uşak, 2004), people threaten the restorative capacity of natural ecosystems. Damage to environmental ecosystems is often related to a lack of environmental and social responsibilities. Hence, people use environmental resources as if they are infinite (Çalık \& Eames, 2012). Those people, who do not choose environmentally friendly practices or products, are called unconscious consumers (Ay \& Ecevit, 2005). For example, poor land use practices can result in 'soil erosion', which adversely impacts the quality and fertility of soil (Bouaziz, Leidig, \& Gloaguen, 2011; Prasannakumar, Vijith, Abinod, \& Geetha, 2012). Such anthropogenic activities as eradicating natural vegetation, destroying forests to open land and long-term effects of fallow can cause erosion. Indeed, erosion poses a major ecologic threat to sustainability, agricultural fertility (Montgomery, 2007) and natural ecosystems (e.g., forestry ecosystems) (Lal \& Stewart, 1990; Pimentel \& Kounang, 1998; Özgen, 2012). That is, an increase in soil erosion not only affects the fertility and quality of agricultural lands but also causes desertification. Soil erosion results in a loss of about 10 million ha of cropland globally each year. Hence, a decrease in the land available for food production is a serious 
PROBLEMS

OF EDUCATION

IN THE $21^{\text {st }}$ CENTURY Vol. 76, No. 5,2018

602

problem resulting in more than 3.7 billion malnourished people in the world (Primentel, 2006). In a similar vein, soil erosion has affected $90 \%$ of agricultural lands in Turkey (Sönmez, Çelik, \& Seven, 2013), in some cases resulting in desertification. A decrease in agricultural land or fertility of the soil can result in a shortage of food due to lower crop and animal production. Because accomplishing future food security for all people relies on preserving fertile soil, water, and biological resources, raising public awareness of the effective protection of our agricultural and natural ecosystems is very important (Primentel, 2006).

Since soil erosion causes irreversible impacts on the fertility of soil, a significant decrease in soil erosion is a high priority for an environmental and sustainable agricultural policy. Soil erosion also damages the quality of water (Bissonnais, Montier, Jamagne, Daroussin, \& King, 2001). Minimizing environmental problems requires environmental education that supports sustainable development. Hence, environmental education in school should stimulate students' environmental interest, sensitivity and awareness of soil erosion and enable students to gain these affective goals (Birişci \& Metin, 2010). In Turkey, students are not only introduced to soil erosion through school courses (social sciences, sciences and geography), but also encounter frequently it in daily life (Özgen, 2013). Because science education is intertwined with environmental issues, science education plays a significant role in facilitating students' understanding and awareness of soil erosion as well as proposing potential solutions to minimize soil erosion (Yılmaz, Morgil, Aktug, \& Göbekli, 2002; Uzun \& Sağlam, 2005; Demirbaş \& Pektaş, 2009). In fact, conceptual understanding has a pivotal role in shaping affective and psychomotor goals (Kiryak \& Çalik, 2018). For instance, understanding the concept of 'erosion' properly not only helps students grasp conservation and sustainability of soil (Özgen, 2013), but also improves their environmental attitudes and practices. In other words, values, cultural issues and perceptions may lead to prejudices, which evolve attitudes over time. Hence, these inferential factors shape people's mental models and conceptual understanding (Akpınar, 2010).

Empowering students with environment education is a pre-request for sustaining a viable and livable environment (Aldrich-Moodie \& Kwong, 1997; Özgen, 2013; Zayimoğlu Öztürk, Bayat, \& Sar1, 2015). Because environmental education is integrated into various scientific disciplines, and courses at different grades in Turkey (Çalık \& Eames, 2012; Demirkaya, 2008), its interdisciplinary framework embraces a lot of stakeholders. For this reason, if all stakeholders (students, teachers, parents, administers, policy makers) effectively support environmental education (Hsu \& Roth 1996), future generations will be able to have healthy and safe environments (Çalık, \& Eames, 2012; Soran, Morgil, Yücel, Atav, \& Işık, 2000; Şahin, Cerrah, Saka, \& Şahin, 2004). Hence, identifying students' pre-existing knowledge may be the first round to improve public awareness of environmental solutions (i.e., forestation against erosion) (Yılmaz et al., 2002; Uzun \& Sağlam, 2005; Demirbaş \& Pektaş, 2009).

Related Turkish curricula do not differentiate the concept of 'erosion' from the 'landslide' one. Phrased differently, Turkish curricula suggest teaching only one of these concepts as a fragmented manner, rather than distinguishing them from each other (MoNE, 2004, 2011, 2015). Landslide is defined as a rapid displacement of a massive rock, residual soil or sediments. Furthermore, a slope and gravity accelerate the massive movement of soil in a downward and outward direction (Cruden, 1991). Rainfall also triggers landslides. For this reason, landslides generally occur in most mountainous landscapes. Moreover, some of the landslides happen suddenly and travel many kilometers at high speeds (Iverson, 2000). On the contrary, soil erosion is described as a gradual wearing away of land surface materials (i.e., rock, sediment and soil) via water, wind etc. Soil erosion generally contains gradual transportation of eroded material from one place to another (Özgen, 2013; The American Heritage Science Dictionary, 2017). The grade 5 science textbook (freely supplied by Ministry of National Education - MoNE - in Turkey) (2015) addresses the 'soil erosion' concept as a displacement of the most fertile layer of the soil via such factors as rainfall, flooding, and wind. Similarly, Turkish science curriculum released in 2013 defines Sustainable Development under Science-Technology-Society-Environment learning field as a 'respectful use of natural 
resources to meet the needs of future generations' (MoNE, 2013). All science teacher education programs in Turkey offer only one course 'Environmental Science' that is directly intended to develop science student teachers' (SSTs) environmental consciousness. In view of a sustainable world, the SSTs are expected to equip students with the idea 'soil is the most important heritage for future generations' (Özgen, 2013). Likewise, the SSTs should improve their understanding and environmental-consciousness of the concept of 'erosion' through courses (with direct and indirect syllabuses) in teacher preparation programs (Özgen, 2013).

\section{Early Studies of Soil Erosion}

The relevant literature has shown that students and student teachers hold alternative conceptions of soil erosion (Alım et al., 2008; Ateş, 2013; Bozkurt et al., 2004; Martinez et al., 2012; Özgen, 2013). For instance; Bozkurt et al. (2004) identified lower secondary school students' (grades 6-8) alternative conceptions of soil erosion. They addressed a confusion between the concept of soil erosion and other concepts (i.e., landslide and earthquake). Also, they reported a lack of sound understanding on the concept of soil erosion. Alım et al. (2008), who elicited grade 5 students' understanding of some daily concepts (e.g., natural disaster, earthquake, climate, soil erosion, landslide), implied a poor understanding. Further, they depicted that the students were unable to explain the difference between soil erosion and landslide. Ateş (2013), who determined high school students' (grades 9-12) understanding of the concept of soil erosion, found that over half of them used the concept of landslide to explain that of soil erosion. Özgen (2013), who drew out preservice elementary teachers' perceptions of the concept of soil erosion, proposed 5 separate categories (e.g., soil erosion means a landslide - Category 1 , attrition of soil - Category 2 and a natural disaster - Category 5) of the concept of soil erosion and 13 different methods (i.e., forestation, making people environmental aware, prevention of forest fires) for soil erosion prevention. Birişçi and Metin (2010), who developed concept cartoons-oriented 5Es instructional model of the soil erosion concept, suggested using these science activities in practicum or science classes. However, even though they designed this teaching design and science activities, they have not tested its effectiveness and applicability.

Reports on 'soil erosion' studies point to several problems: (1) inability to explain how soil erosion takes place (Bozkurt et al., 2004; Alım et al., 2008; Özgen, 2013), (2) confusing soil erosion with earthquake and/or landslide (Ateş, 2013; Özgen, 2013), (3) failing to grasp the factors causing soil erosion (Russell, Bell, Longden, \& McGuigan, 1993; Martinez et al., 2012; Turan \& Kartal, 2012; Zayimoğlu Öztürk et al., 2015), and (4) a lack of discriminating pedogenesis from soil erosion (Bozkurt et al., 2004; Demirbaş \& Pektaş, 2009; Ateş, 2013; Özgen, 2012, 2013). These studies indicate that soil erosion is the most crucial environmental issue determining the quality and fertility of soil. Even though the SSTs are expected to teach the concept of 'soil erosion' in lower secondary schools (grades 5-8), none of the foregoing studies have investigated their conceptual growth and/or mental models throughout a 4-year undergraduate program. Such an unexplored issue in the related literature calls for the current research.

A mental model is viewed as a reflection of conceptual framework in the mind (Vosniadou \& Brewer, 1992). Mental models not only reflect people's worldviews but also shape their beliefs, thoughts and conceptions (Franco \& Colinvaux, 2000; Örnek, 2008; İyibil \& Sağlam Arslan, 2010). Harrison and Treagust (2000) note that mental models are outcomes of formal education and pre-existing knowledge. For this reason, eliciting the SSTs' mental models informs researchers, educators, and curriculum developers about how to enhance their understanding and environmental consciousness of soil erosion. Also, the current research would provide more insights on the SSTs' understanding of the 'soil erosion' concept over year. Hence, science (student) teachers would not only have an opportunity to notice the sustainability of soil as an environmental heritage for future generations but also to transfer 
PROBLEMS

OF EDUCATION

IN THE $21^{\text {st }}$ CENTURY Vol. 76, No. 5, 2018

604

their environmental knowledge and mental models to younger generations. Because science (student) teachers act as a milestone to teach the sustainability of soil as an environmental heritage, the SSTs' understanding of 'soil erosion' may be seen as achievement indicators of science curriculum and sustainable development.

\section{Aim of Research}

The aim of this research was to elicit the SSTs' conceptual understanding of soil erosion throughout a four-year science education program. The following research questions guided the current research:

1. How do the SSTs' understanding of soil erosion change through the four-year science education program?

2. What mental models of soil erosion do the SSTs hold?

\section{Methodology of Research}

\section{General Background}

This research employed an interpretivist approach highlighting a set of social meanings reflecting cultural beliefs, values, and worldviews (Roth \& Mehta, 2002). That is, the current research elicited the SSTs' mental models and conceptual understanding of soil erosion. Hence, the interpretivist approach purposing to unravel patterns of subjective understanding (Roth \& Mehta, 2002) led the authors to shape the soil erosion through the SSTs' understanding. Overall, the interpretivist approach helped to ask the right questions to interpret and discuss the results of the current research (King, Keohane, \& Verba, 1994).

Cross-age and longitudinal comparisons portray how students' understanding changes over the years (Çalık, 2005; Çalık, Ültay, Kolomuç, \& Aytar, 2015; Gökdere \& Çalik, 2010). However, both types of research have their own pros and cons. For example, a longitudinal comparison explicitly measures individual consistency/change over time (Çalık et al., 2015); but it includes several deficiencies (cost, time, labor-intensive, missing samples, several interactions with data collection instrument(s), a decrease in participant interest/motivation) (Çalık et al., 2015). On the contrary, a cross-age comparison is inexpensive, time-efficient and involves a one-time interaction with data collection instrument that minimizes sample missing and participant interest/motivation (Abraham, Williamson, \& Westbrook, 1994; Çalık, 2005; Çalık et al., 2015; Gökdere \& Çalik, 2010). Therefore, given the aforementioned issues, the authors found a cross-age comparison more applicable for their research context than a longitudinal one.

\section{Sample}

The sample of the research comprised of the first-year $(n=54$, mean age: 19.2, 46 females and 8 males), second-year ( $\mathrm{n}=62$, mean age: $20.3,44$ females and 18 males $)$, third-year $(\mathrm{n}=60$, mean age: 21.7, 41 females and 19 males), and fourth-year of a four-year science education program ( $n=65$, mean age: 22.6, 44 females and 21 males), a total of 241 SSTs, enrolled at Fatih Faculty of Education, Karadeniz Technical University, in the spring semester of 20142015 academic year. Socioeconomically, the participants in the research came from low- and medium-income families. Furthermore, Karadeniz Technical University, Trabzon was founded in Eastern Black Sea Region of Turkey in which landslide disasters have frequently occurred (Filiz \& Avc1, 2013). 
After upper secondary school, students take high stakes nation-wide exams conducted by the Measurement, Selection and Placement Center (Ölçme, Seçme ve Yerleştirme Merkezi ÖSYM) in Turkey. Then, using their scores of centralized exams and grade point average in upper secondary school, they prepare a list of undergraduate programs and submit to the Measurement, Selection and Placement Center. Given their preference lists and scores, they are centrally placed into undergraduate programs.

In looking for 'soil erosion and landslide' concepts in Turkish curricula, students are firstly introduced to the concept 'landslide' within the 'Nature and Environment' unit in grade 2 'Knowledge of Life' curriculum (MoNE, 2015). Later, they encounter the concepts 'soil erosion and landslide' in grade 5 science curriculum (MoNE, 2013). Further, grade 5 social studies curriculum includes an implicit objective: 'notice human activities increasing the natural disasters in the local environment' (MoNE, 2004). Also, grade 10 geography curriculum links the concept 'soil erosion' with types of soil as well as the impact of soil erosion on the environment (MoNE, 2011). In the second year of the four-year science education program, the SSTs attend the 'Science Curriculum and Planning' course (28 class hours in a semester) that requires them to go over science curriculum and to prepare course plans for science concepts (e.g., landslide and soil erosion). Also, the SSTs follow the 'Science Teaching I-II' courses (a total of 56 class hours in a semester) embracing micro-teaching sessions and lesson plans drawn from science curricula (grades 5-8). Furthermore, the SSTs take the 'Environmental Science' course (a total of 28 class hours in a semester) in the fourth year of the four-year science education program that requires them to elaborate the concepts 'landslide and soil erosion' and to improve their environmental awareness, and problem-solving skills in relation to environmental issues. Besides, the SSTs, who attend the 'Teaching Practice' course in the fourth year of the four-year science education program, prepare and practically implement lesson plans (the concepts 'landslide and soil erosion') in science classes at lower secondary schools. To be employed in the state schools, the SSTs have to pass another high-stakes nationwide exam, which covers several questions from the 'environmental science' course. Overall, the current research related the timing of the research to data collection tools by administering them at the end of the relevant courses.

\section{Data Collection Tools}

A questionnaire with 4 open-ended questions and semi-structured interviews were exploited to gather data.

\section{Questionnaire}

The fourth question of the questionnaire asked the participants to draw their mental models of the concept of 'soil erosion'. Two experienced science educators (11 and 25 years of experience) examined the questionnaire and ensured its content validity. The questionnaire was pilot-tested with a total of 12 of the SSTs (3 from each year of the four-year science education program), who did not participate in the final research. Hence, its comprehensibility and readability were tested. The pilot-research revealed that some of the SSTs only focused on one dimension of the question 'Define soil erosion and explain the factors causing soil erosion' (either definition of soil erosion or the factors causing soil erosion). Consequently, this question was divided into two separate ones. The final version of the questionnaire was in the following:

1. How do you define the concept of 'soil erosion'? Please explain your response.

2. What factor(s) cause(s) soil erosion? Please explain your response.

3. What methods of soil erosion prevention do you know? Please explain your response. 
PROBLEMS

OF EDUCATION

IN THE $21^{\text {st }}$ CENTURY

Vol. 76, No. 5,2018

606

4. Given the concept of 'soil erosion', please draw your mental model.

The questionnaire was administered to the SSTs at the end of spring semester of 20142015 academic year to catch the timing of the events that took place in the courses.

Interview

Semi-structured interviews were carried out with a total of 12 SSTs randomly drawn from volunteer SSTs (S6, S22, S49, S63, S75, S81, S127, S135, S172, S179, S233, S240). The semi-structured interviews were employed for data triangulation. Each interview, which took approximately 8-12 minutes, was tape-recorded. The interview questions were pilot-tested with 4 SSTs, who did not participate in the final research (One from each year of the fouryear science education program). Two science educators (with 11 and 25 years of experience) examined the interview protocol and ensured its comprehensibility. The pilot-research revealed that the SSTs tended to provide a definition of soil erosion but failed to properly explain how it takes place. For this reason, this question (How can you explain the concept of 'soil erosion' and its occurrence?) was divided into two separate questions (How can you define the concept of 'soil erosion'? How does soil erosion occur?). The final version of the interview questions is as follows:

1. How can you define the concept of 'soil erosion'?

2. How does soil erosion occur?

3. What do you think about factors causing soil erosion?

4. What methods of soil erosion prevention do you know?

The interview protocols were conducted with the interviewees after administering the questionnaire.

\section{Data Analysis}

The SSTs' responses to Questions 1-3 were exposed to inductive content analysis to identify their similarities and differences. Hence, their responses to the questionnaire yielded all attributes (codes). For Question 4, their drawings were analyzed against the following criteria: scientific drawing (including relocation or displacement, attrition, and cracking of soil as well as attrition of rocks), alternative drawing (referring to landslide) and no drawing. Further, a sound mental model of this concept handles these related key words in the SSTs' drawings. Moreover, their sample drawings were also presented to illustrate their mental models. Hence, their responses in each code were counted and transformed into percentages.

In analyzing interview data, the SSTs' responses were thematically examined and classified through categories suggested by Marek, 1986 (e.g., sound understanding, partial understanding, and alternative understanding). For example; a sound understanding of the concept of 'soil erosion' includes such key words as external factors (wind, river) resulting in the attrition and displacement of soil; displacement or relocation, attrition and cracking of soil, and attrition of rocks. Further, partial understanding contains at least a component of the validated response (i.e., referring to only the impact of water or excessive rainfall or flood or rivers on the relocation of fertile soil). Also, each category was sampled with an interview quotation. Given research ethics, the SSTs were presented with numerical codes. For example, S6 referred to the sixth science student teacher in the sample of the research.

\section{Results of Research}

As seen in Table 1, percentages of the SSTs' responses classified under 'landslide' are $46 \%$ for the first-year SSTs, $42 \%$ for the second-year SSTs, and $20 \%$ for the third-year and fourth-year SSTs, whilst those for 'The factors (wind, rivers etc.) resulting in the attrition and displacement of soil' code are 7\%, 14\%,33\% and 57\% respectively. Also, the percentages of 
the SSTs' responses labeled under 'The effects of highly sloping land and rainfall on the slide of soil' code are $17 \%$ for the first-year SSTs, $14 \%$ for the second-year SSTs and 10\% for the

PROBLEMS OF EDUCATION IN THE $21^{\text {st }}$ CENTURY Vol. 76, No. 5, 2018

607 third-year SSTs whereas those for 'The effect of excessive rainfall on the slide of soil' code are respectively $13 \%, 11 \%, 8 \%$ and $3 \%$ over an increase in the year of the science education program. This means that the SSTs' responses classified under 'alternative understanding' decreased from the first-year to the fourth year of the science education program.

Table 1. Percentages of the SSTs' responses to question 1.

\begin{tabular}{|c|c|c|c|c|}
\hline Codes & $\begin{array}{l}\text { The first-year } \\
\text { SSTs }\end{array}$ & $\begin{array}{l}\text { The second- } \\
\text { year SSTs }\end{array}$ & $\begin{array}{l}\text { The third- } \\
\text { year SSTs }\end{array}$ & $\begin{array}{l}\text { The fourth-year } \\
\text { SSTs }\end{array}$ \\
\hline $\begin{array}{l}\text { The factors (wind, rivers etc.) resulting in the } \\
\text { attrition and displacement of soil }\end{array}$ & 7 & 14 & 33 & 57 \\
\hline Landslide & 46 & 42 & 20 & 20 \\
\hline Attrition of soil & 7 & 15 & 13 & 18 \\
\hline Displacement of soil & 6 & 3 & 8 & 2 \\
\hline $\begin{array}{l}\text { The effect of excessive rainfall on the slide } \\
\text { of soil }\end{array}$ & 13 & 11 & 8 & 3 \\
\hline $\begin{array}{l}\text { The effects of highly sloping land and rainfall } \\
\text { on slide of the soil }\end{array}$ & 17 & 14 & 10 & - \\
\hline A natural disaster & 4 & 5 & - & - \\
\hline $\begin{array}{l}\text { The effect of excessive water on a decrease } \\
\text { in minerals in the soil }\end{array}$ & - & - & 8 & - \\
\hline
\end{tabular}

As can be seen in Table 2, the SSTs' responses to Question 2 categorized under 'Sparse vegetation' code are 59\% for the first-year SSTs, 55\% for the second-year SSTs, $62 \%$ for the third-year SSTs and 38\% for the fourth-year SSTs, while those for 'excessive rainfall' code are $52 \%, 47 \%, 40 \%$ and $29 \%$ respectively. This means that the SSTs' responses of 'sparse vegetation' and 'excessive rainfall' codes decreased from the first-year to the fourth-year of the science education program. Percentages of their responses in 'slope' code from the first-year to the fourth-year of the science education program are $48 \%, 16 \%, 25 \%$ and $14 \%$ respectively, while those for 'wind' code are $6 \%, 19 \%, 38 \%$ and $52 \%$ respectively. This reveals that the SSTs' responses of 'wind' code increased from the first-year to the fourth-year of the science education program. For the 'slope' code, the first-year SSTs possessed the highest percentage amongst all years of the science education program. 
Sibel ER NAS, Muammer ÇALIK. A cross-age comparison of science student teachers' conceptual understanding of soil erosion

PROBLEMS

OF EDUCATION

IN THE $21^{\text {st }}$ CENTURY

Vol. 76, No. 5, 2018

608

Table 2. Percentages of the SSTs' responses to question 2.

\begin{tabular}{|c|c|c|c|c|}
\hline Codes & $\begin{array}{l}\text { The first-year } \\
\text { SSTs }\end{array}$ & $\begin{array}{l}\text { The second-year } \\
\text { SSTs }\end{array}$ & $\begin{array}{l}\text { The third-year } \\
\text { SSTs }\end{array}$ & $\begin{array}{l}\text { The fourth-year } \\
\text { SSTs }\end{array}$ \\
\hline Slope & 48 & 16 & 25 & 14 \\
\hline Excessive rainfall & 52 & 47 & 40 & 29 \\
\hline Wind & 6 & 19 & 38 & 52 \\
\hline Incorrect use of land & 4 & 19 & 17 & 52 \\
\hline Floods and rivers & 13 & 15 & 40 & 32 \\
\hline A long period of fallowing of land & - & 8 & 3 & 28 \\
\hline Sparse vegetation & 59 & 55 & 62 & 38 \\
\hline Uncontrolled logging & 19 & 11 & 17 & 22 \\
\hline $\begin{array}{l}\text { Natural disasters (earthquake, } \\
\text { etc.) }\end{array}$ & 17 & 11 & 13 & 5 \\
\hline Structure of soil & 6 & 35 & 12 & 12 \\
\hline Changes in temperature & 4 & 3 & 2 & 11 \\
\hline $\begin{array}{l}\text { Irregular and scattered settle- } \\
\text { ments }\end{array}$ & - & 27 & 12 & 8 \\
\hline Climate & 19 & 19 & 10 & 11 \\
\hline Drought & 11 & 11 & 7 & 14 \\
\hline Infertile soil & 15 & - & 5 & 6 \\
\hline Geographical formations & 6 & 5 & - & 6 \\
\hline Irregular rainfall & - & - & - & 8 \\
\hline
\end{tabular}

As seen in Table 3, percentages of the SSTs' responses to Question 3 classified under the 'forestation' code are $91 \%$ for the first-year and second-year SSTs, $88 \%$ for the third-year SSTs and $89 \%$ for the fourth-year SSTs, whilst those for the 'Building terraces on sloped hills' code are $11 \%, 19 \%, 27 \%$ and $5 \%$ respectively. This indicates that the SSTs' responses of the 'forestation' code were almost the same percentage, whereas those for 'Building terraces on sloped hills' code showed an inverse U-shaped developmental curve over the year. Percentages of their responses labeled under 'Building settlement on slopes' code are $24 \%$ for the firstyear SSTs, $11 \%$ for the second-year SSTs, and $12 \%$ for the third-year SSTs, whereas those for 'Conservation of soil by reducing the impact of wind' code are $7 \%$ for the third-year SSTs and $15 \%$ for the fourth-year SSTs. This points that all SSTs, except for the fourth-year of the science education program, referred to the 'Building settlement on slopes' code. Also, only upper grades (the third-year and fourth-year SSTs) dealt with the 'Conservation of soil by reducing the impact of wind' code. 
Table 3. Percentages of the SSTs' responses to question 3.

\begin{tabular}{lllll}
\hline Codes & $\begin{array}{l}\text { The first- } \\
\text { year SSTs }\end{array}$ & $\begin{array}{l}\text { The second- } \\
\text { year SSTs }\end{array}$ & $\begin{array}{l}\text { The third-year } \\
\text { SSTs }\end{array}$ & $\begin{array}{l}\text { The fourth- } \\
\text { year SSTs }\end{array}$ \\
\hline Forestation & 91 & 91 & 88 & 89 \\
\hline Building terraces on sloped hills & 11 & 19 & 27 & 5 \\
\hline Conservation of vegetation & 13 & 5 & 25 & 15 \\
\hline $\begin{array}{l}\text { Making people environmental aware- } \\
\text { ness }\end{array}$ & 2 & 14 & 18 & 18 \\
\hline Building settlement on slopes & 24 & 11 & 12 & - \\
\hline $\begin{array}{l}\text { Conservation of soil by reducing the } \\
\text { impact of wind }\end{array}$ & - & - & 7 & 15 \\
\hline Increasing soil fertile & 9 & 8 & - & 3 \\
\hline Use of natural fertilizers & 13 & - & - & - \\
\hline Prevention of excessive use of pastures & 4 & - & - & 23 \\
\hline Preferring crop rotation to fallowing & - & - & 7 & 2 \\
\hline Preferring proper irrigation techniques & 4 & - & 12 & 5 \\
\hline Prevention of forest fires & - & - & - & 6 \\
\hline Planned urbanization & - & - & - & \\
\hline
\end{tabular}

As seen in Table 4, percentages of their drawings classified under 'Displacement or relocation of soil' code are 7\% for the first-year SSTs, $11 \%$ for the second-year SSTs, $20 \%$ for the third-year SSTs and 43\% for the fourth-year SSTs, while those for 'landslide' code in the alternative drawing category are $76 \%, 70 \%, 48 \%$ and $19 \%$ respectively. This means that whilst the percentages of the SSTs' drawings in the 'Displacement or relocation of soil' code increased from the first-year to the fourth-year of the science education program, those for the 'landslide' code decreased along the same line.

Table 4. Percentages of the SSTs' drawings to question 4.

\begin{tabular}{llllll}
\hline Category & Codes & $\begin{array}{l}\text { The first-year } \\
\text { SSTs }\end{array}$ & $\begin{array}{l}\text { The second- } \\
\text { year SSTs }\end{array}$ & $\begin{array}{l}\text { The third- } \\
\text { year SSTs }\end{array}$ & $\begin{array}{l}\text { The fourth- } \\
\text { year SSTs }\end{array}$ \\
\hline & $\begin{array}{l}\text { Displacement or relocation } \\
\text { of soil }\end{array}$ & 7 & 11 & 20 & 43 \\
\cline { 2 - 6 } $\begin{array}{l}\text { Scientific } \\
\text { drawing }\end{array}$ & Attrition of soil & 4 & 8 & 10 & 23 \\
\cline { 2 - 6 } & Cracking of soil & - & - & 5 & 6 \\
\hline & Attrition of rocks & - & 3 & 10 & 7 \\
\hline $\begin{array}{l}\text { Alternative } \\
\text { drawing }\end{array}$ & Landslide & 76 & 70 & 48 & 19 \\
\cline { 2 - 6 } & No drawing & 13 & 8 & 7 & 2 \\
\hline
\end{tabular}

As seen in Figure 1, the SSTs' drawings classified as 'scientific drawings' increase from the first-year to the fourth-year of the science education program, while their drawings labeled as 'alternative drawings' decrease through the four-year science education program. 
PROBLEMS

OF EDUCATION

IN THE $21^{\text {st }}$ CENTURY

Vol. 76, No. 5, 2018

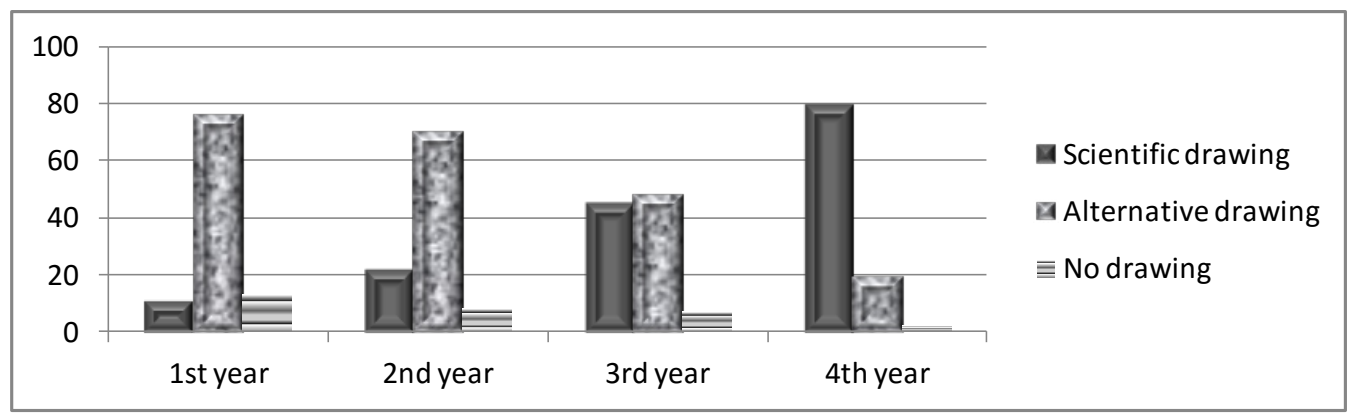

Figure 1. Percentages of the SSTs' drawings.

Some sample drawings in the 'scientific drawing' category are shown in Figure 2.

Displacement or relocation of soil

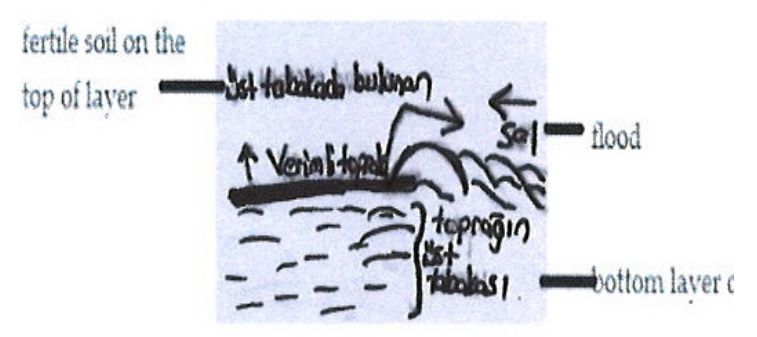

The fourth-year SSTs

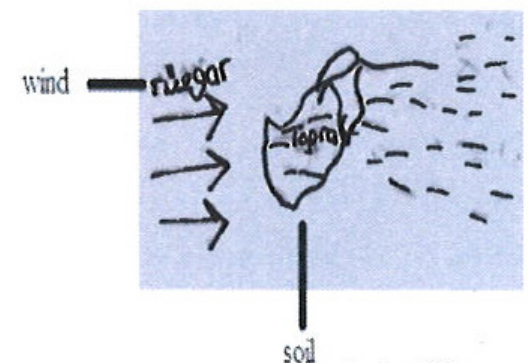

The third-year SSTs

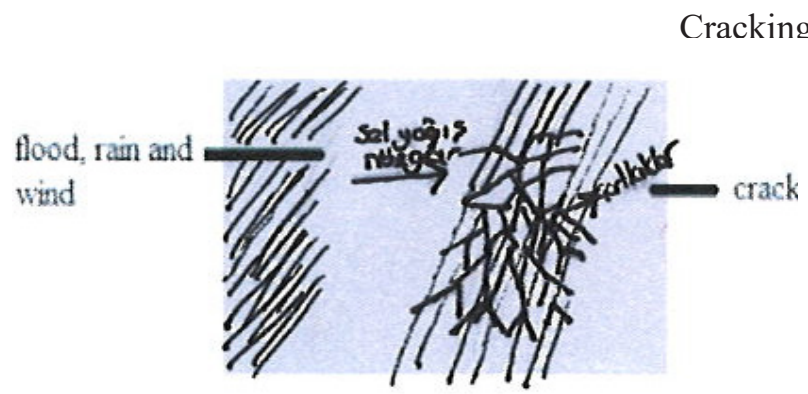

The fourth-year SSTs

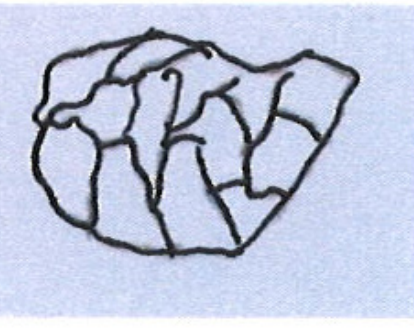

The third-year SSTs

Attrition of rocks 


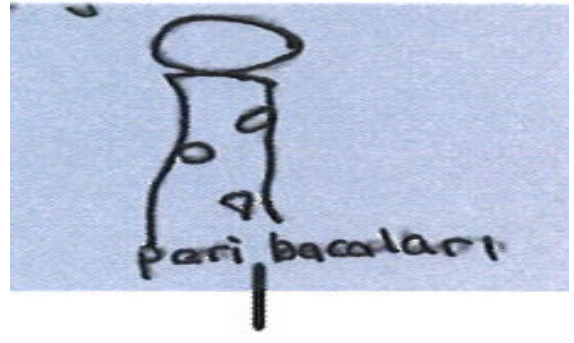

fairy chimneys

The fourth-year SSTs

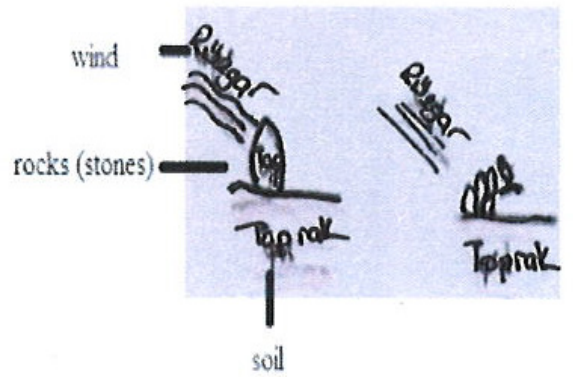

The second-year SSTs

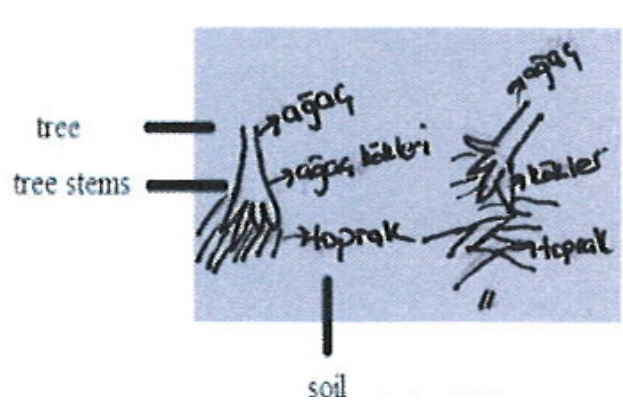

The third-year SSTs

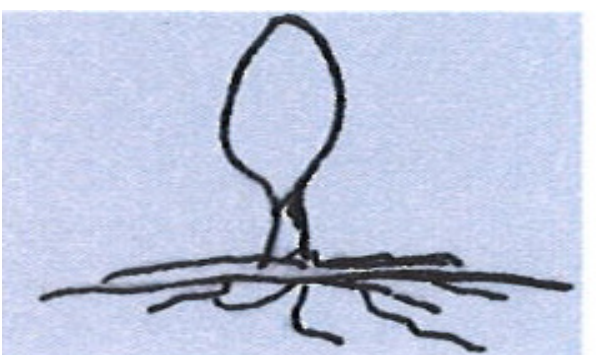

The second-year SSTs

Figure 2. Some sample drawings in the 'scientific drawing' category.

(All Turkish words in the SSTs' original drawings were translated into English).

Some sample drawings in the 'alternative drawing' category are displayed in Figure 3.

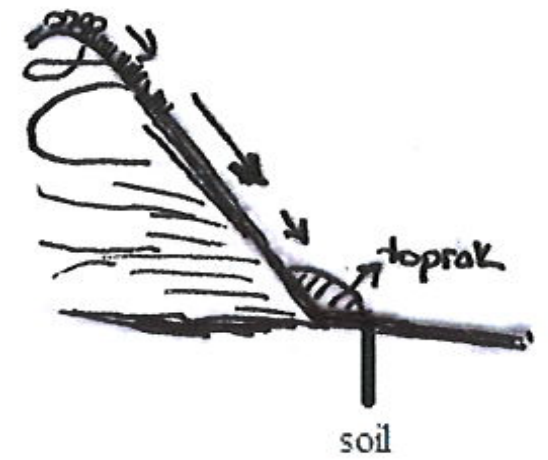

The first-year SSTs

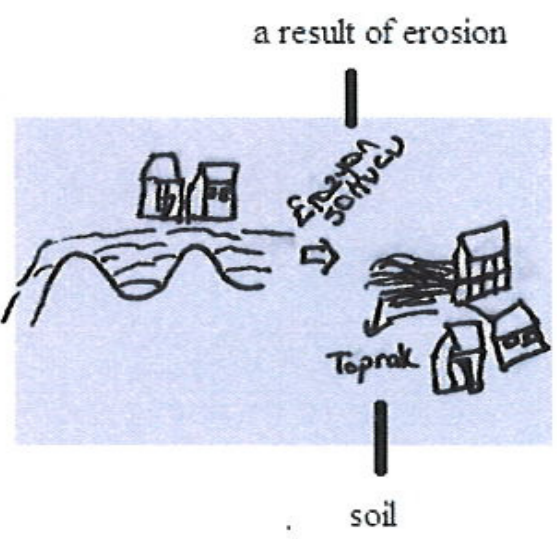

The first-year SSTs
OF EDUCATION

IN THE $21^{\text {st }}$ CENTURY

Vol. 76, No. 5, 2018

611 
PROBLEMS

OF EDUCATION

IN THE $21^{\text {st }}$ CENTURY

Vol. 76, No. 5, 2018

612

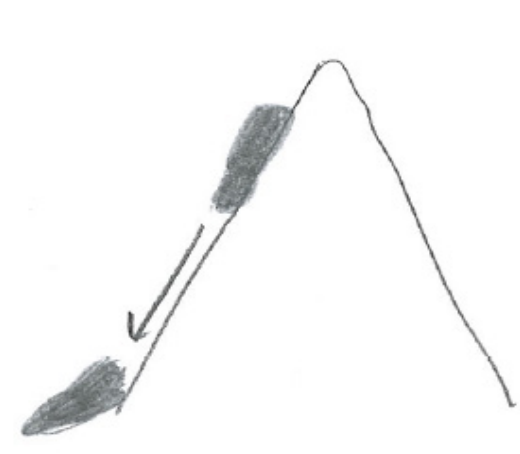

The second-year SSTs

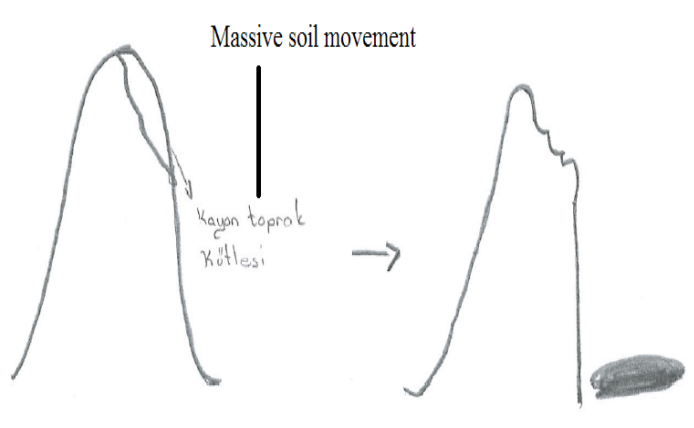

The second-year SSTs

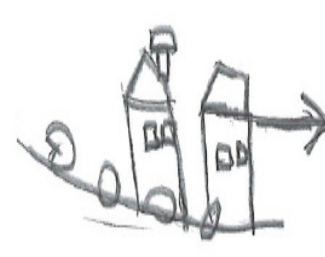

The third-year SSTs

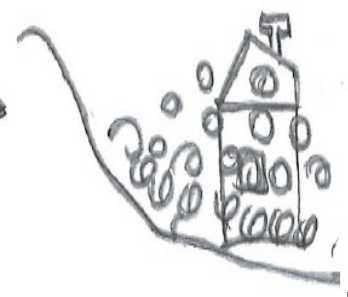

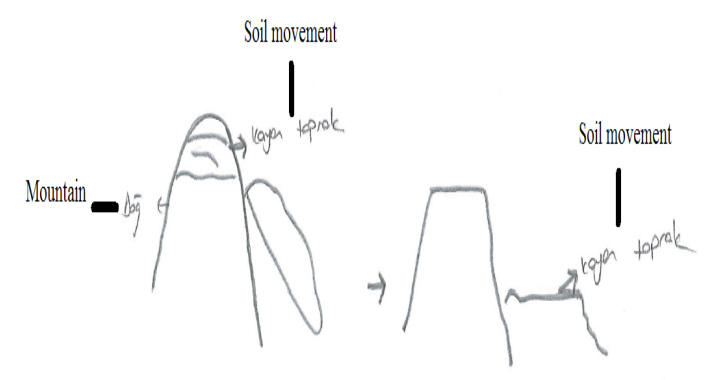

The first-year SSTs

Figure 3. Some sample drawings in the 'alternative drawing' category. (All Turkish words in the SSTs' original drawings were translated into English).

The interviewees' responses to the interview questions are presented in Table 5. 
Table 5. The interviewees' responses to the interview questions.

\begin{tabular}{|c|c|c|c|c|c|}
\hline \multirow[b]{2}{*}{$\begin{array}{l}\text { Inter- } \\
\text { view } \\
\text { Ques- } \\
\text { tions }\end{array}$} & \multirow[b]{2}{*}{$\begin{array}{l}\text { Understand- } \\
\text { ing Level }\end{array}$} & \multicolumn{4}{|c|}{ The SSTs' Codes } \\
\hline & & $\begin{array}{l}\text { The } \\
\text { first- } \\
\text { year } \\
\text { SSTs }\end{array}$ & $\begin{array}{l}\text { The } \\
\text { sec- } \\
\text { ond- } \\
\text { year } \\
\text { SSTs }\end{array}$ & $\begin{array}{l}\text { The } \\
\text { third- } \\
\text { year } \\
\text { SSTs }\end{array}$ & $\begin{array}{l}\text { The } \\
\text { fourth- } \\
\text { year } \\
\text { SSTs }\end{array}$ \\
\hline $\begin{array}{l}\text { ㄷ. } \\
\text { 음 } \\
\text { 인 } \\
\frac{0}{\overline{0}}\end{array}$ & $\begin{array}{l}\text { Sound Under- } \\
\text { standing }\end{array}$ & - & - & S127 & $\begin{array}{l}\text { S179, } \\
\text { S233 }\end{array}$ \\
\hline 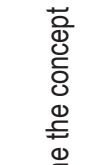 & $\begin{array}{l}\text { Partial Under- } \\
\text { standing }\end{array}$ & - & S63 & $\begin{array}{l}\text { S135, } \\
\text { S172 }\end{array}$ & S240 \\
\hline $\begin{array}{l}\text { 을 } \\
\text { 옺 } \\
\text { 덩 } \\
\text { 공 } \\
\text { 오 }\end{array}$ & $\begin{array}{l}\text { Alternative } \\
\text { Understand- } \\
\text { ing }\end{array}$ & $\begin{array}{l}\text { S6, S22, } \\
\text { S49 }\end{array}$ & $\begin{array}{l}\text { S75, } \\
\text { S81 }\end{array}$ & - & - \\
\hline
\end{tabular}

Soil erosion is the attrition of soil and damages its fertility. Such external forces as water and wind result in the displacement of soil.

Erosion has a number of causes, e.g. wind. Wind erosion constituted Hoodoos in Cappadocia, Turkey. The wind shaped and formed the Hoodoos. In brief, we can define erosion as the attrition and relocation of soil (S233) The soil relocates with the impact of water. An excessive rainfall brings about flood, which leads to the relocation of fertile soil. Namely, it is defined as the relocation of soil via water (S135).

can define soil erosion as landslide. Let me give an example. There was a coffee shop on the road to Maçka. Then, a landslide occurred, and completely buried the coffee shop. Soil erosion is defined as a natural disaster (S81)

Sparse vegetation causes a capacity decrease in the roots of the vegetation that hold

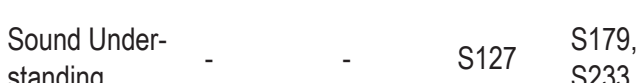
water. Hence, the water moves the fertile

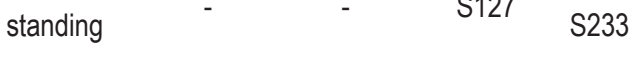
soil gradually. The same case is valid for the wind. To sum up, soil erosion occurs through the attrition and displacement of soil due to such factors as water, wind, river, and flood (S179).

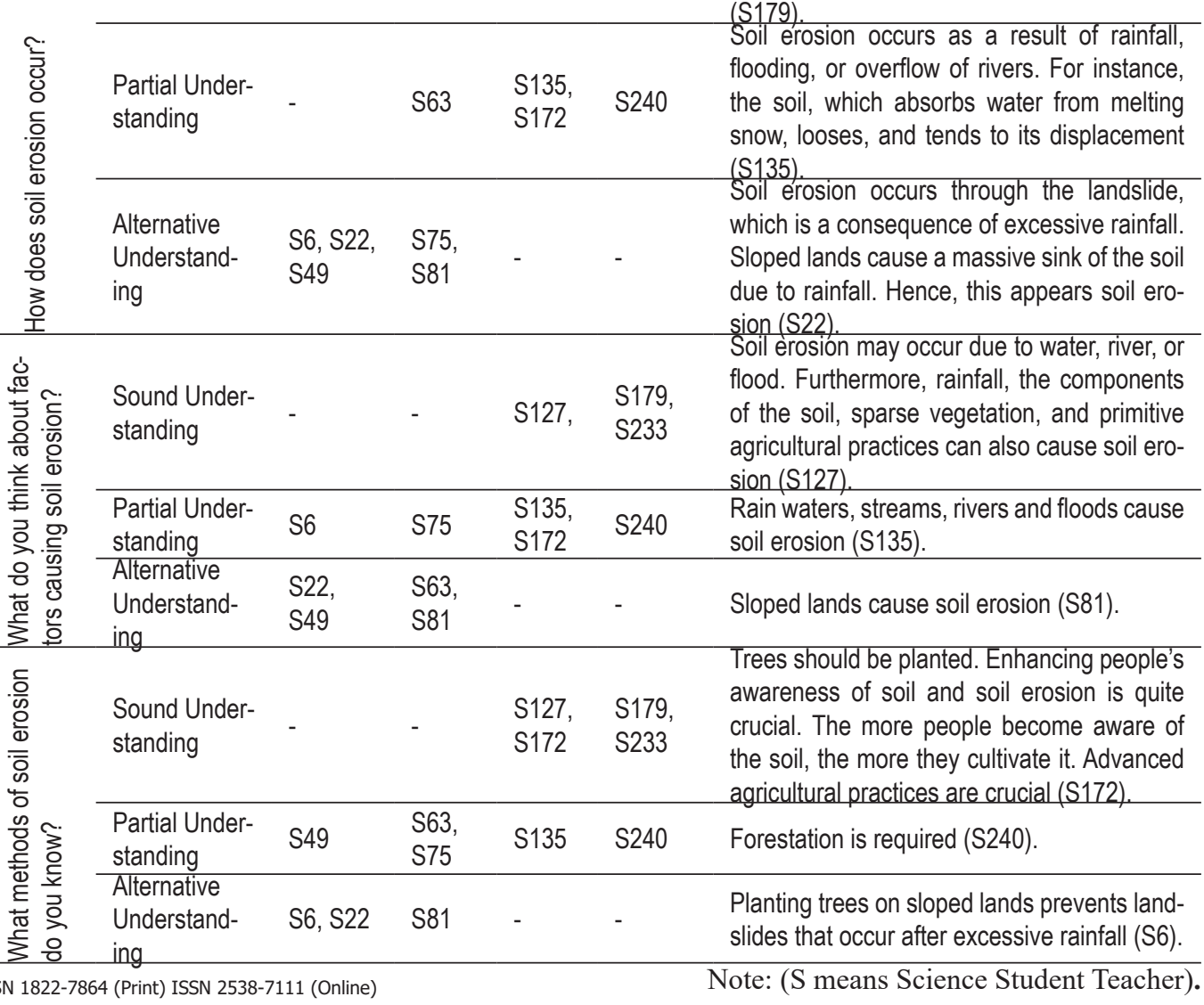


PROBLEMS

OF EDUCATION

IN THE $21^{\text {st }}$ CENTURY Vol. 76, No. 5, 2018

614

As indicated in Table 5, the interviewees' responses to the interview questions mostly fell into the 'alternative understanding' category for the first-year and second-year SSTs, while those the third-year and fourth-year SSTs were classified under 'partial understanding' and 'sound understanding' categories.

\section{Discussion}

As seen in Tables 1-5 and Figure 1, the SSTs' responses to the concept of 'soil erosion' got closer to the scientific view over the year of the science education program. This may result from the 'environmental science' course in the fourth-year of the science education program that explains fundamental ecological concepts, and develops problem solving skills related to the environmental problems. The fact that the 'environment science' course directly handles soil erosion and its prevention methods seem to have increased their understanding and environmental awareness of 'soil erosion'. Moreover, this may stem from a high-stakes nationwide exam (named Public Personnel Selection Exam) covering questions on the 'environmental science' course. Improvements in the SSTs' understanding and mental models of the concept of 'soil erosion' may also come from the course 'Science Curriculum and Planning' that examines how to plan and teach this concept within science curriculum. Moreover, this may result from the 'Science Teaching I-II' and 'Teaching Practice' courses embracing micro-teaching sessions, lesson plans and practices in real science classes. That is, these issues seem to have resulted in improvements in their drawings and conceptual understanding from the first year to the fourth year of the science education program.

The confusion between the concepts of 'soil erosion and landslide' (see Table 1) (Bozkurt et al., 2004; Alım et al., 2008; Pınar \& Akdağ 2012; Ateş, 2013; Özgen, 2013) may result from climatic and environmental (see Table 2 and Figure 3) characteristics of the city in the current research. For example; landslide disasters have frequently occurred in Eastern Black Sea Region of Turkey covering the city of the current research (Filiz \& Avc1, 2013). Since agricultural land in Trabzon is very limited, protecting fertile soil is very important for the residents. In a similar vein, the fact that news and social media exploit interchangeably the concepts 'soil erosion and landslide' may have influenced their conceptual understanding and alternative conceptions. This means that sociocultural issues (i.e., values, beliefs, worldviews) may influence their conceptual understanding and mental models of soil erosion (Akpinar, 2010). The SSTs tended to link the concept of 'soil erosion' with slopes and rainfall. This may result from their daily life experiences of excessive rainfall, which is a major contributor to soil erosion (see Table 5). Some natural disasters might highly influence people's informal learning even though they happened several years ago. For example, the landslide on June 23, 1988 at Maçka, in the city of Trabzon, resulted in the death of 64 people. Because of this disaster, they may interchangeably use the concepts of 'soil erosion and landslide'. Such daily life language may reinforce this confusion and/or alternative conception (Chi, 1992; Kortz \& Murray, 2009; Özgen, 2013). In other words, inconsistency between daily life and scientific languages may often result in alternative conceptions (Ültay \& Çalik, 2016). Further, this may stem from their pre-existing knowledge and/or prior experiences. For example, previous studies with varied samples (e.g., science student teachers, social studies student teachers, and primary school student teachers- Özgen, 2013; upper secondary school students - Ateş, 2013; and grade 5 students - Alım et al., 2008) emphasized the inability to imagine the concept of 'soil erosion' and to deal with the aforementioned alternative conceptions.

As seen in Table 2, percentages of the SSTs' responses to Question 2 classified under the 'natural disasters (earthquake, etc.)' code were $17 \%, 11 \%, 13 \%$ and $5 \%$ respectively in the year of the science education program. A confusion between the concept of 'soil erosion' and natural disaster(s) (e.g., earthquakes) may result from overgeneralization of any natural disaster (e.g., landslide). Because earthquakes generally result in landslides, they may have related landslide to the concept of 'soil erosion' (Malamud, Turcotte, Guzzetti, \& Reichenbach, 2004; Keefer, 2002). 
Furthermore, such difficulty may arise from the interdisciplinary nature of 'soil erosion' as a concept in the related curricula. For instance, the 'Knowledge of Life' curriculum embraces the concept of 'landslide' in grade 2 (MoNE, 2015); science curriculum includes the concepts of 'erosion and landslide' in grade 5 (MoNE, 2013); grade 5 in the social studies curriculum implicitly contains the relationship(s) between human activities and natural disasters (e.g., landslide) (MoNE, 2004); and grade 10 in the geography curriculum stresses the concept of 'soil erosion' (MoNE, 2011). However, these concepts have not been differentiated from each other. Phrased differently, the related curricula only focus on one of these concepts instead of discerning them from one another. The fact that most of the SSTs referred to 'forestation' as a prevention method to minimize/eliminate soil erosion may result from public announcements/ broadcasts by Turkish government and non-profit organizations (e.g., Turkish Foundation for Combating Soil Erosion, for Reforestation and the Protection of Natural Habitats/TEMA Vakfi).

Because learning is an acculturation process, any result of the current research is of interest in international environmental education/educators. That is, in a globalized world, any problematic issue directly or indirectly influences people's worldviews. Hence, problem solving strategies call for any cognitive activity deploying mental models (Jonassen, 2000; Vosniadou \& Brewer, 1992). Although students in different regions have different classcultures (meaning family income, socio-economic statute, parents' educational levels, and worldview), the related literature indicates their similar pitfalls in learning science (Çalik \& Cobern, 2017). For this reason, even though the SSTs' mental models may be viewed from a national context, different students and/or student teachers and/or teachers may hold similar ones. Because soil erosion directly threatens our future food security, fertile soil, energy, water and biological resources (Primentel, 2006), we should work hard to raise people's awareness of soil erosion over the world. Therefore, the SSTs' mental models identified in the current research will inform researchers, educators, and curriculum developers about how to enhance their students' conceptual understanding and environmental consciousness of soil erosion. To sum up, it is believed that any decision-making continuum and argumentation procedure (Bağ and Çalık, 2017; Erduran and Jimenez-Aleixandre, 2007) start in the mind via mental models; so, any teaching intervention research may exploit the findings of the current research to inform participants about 'soil erosion'.

\section{Conclusions and Recommendations}

To sum up, the results of this research indicated that the majority of the SSTs confused the concept of 'soil erosion' with that of 'landslide'. Therefore, discriminating the concepts of 'soil erosion and landslide' from one another should clearly be integrated into the related curricula, especially at the primary level. Furthermore, taking the SSTs' alternative conceptions into account, argumentation activities to equip them with argumentation and reasoning skills should be deployed. Hence, argumentation competing their alternative conceptions with each other stimulates their reasoning skills to justify or refute any different claim. This process facilitates them to create a scientific consensus in constructing knowledge. Also, analogies and computer simulations ought to be devised to develop their mental models of the concepts of 'soil erosion and landslide'. Thus, analogies and computer simulations enable students to make these concepts meaningful with concrete examples/experiences by differentiating the concepts of 'soil erosion and landslide' from each other. Moreover, an applied course 'conservation of soil and water' should be inserted into primary school curricula as well as teacher preparation programs. Situated learning approaches (e.g., field trips, project-based learning) should be carried out to observe the effects on the concepts of 'soil erosion and landslide' on the soil and the sustainability of soil. Thereby, they may have an opportunity to get first-hand experiences through their own observations. For example, Sera Lake in the city of Trabzon in Turkey, which appeared after a well-known landslide, may be visited for such a field trip. Furthermore, hands-on and minds-on activities ought to be designed and implemented to teach

\begin{tabular}{|l} 
PROBLEMS \\
OF EDUCATION \\
IN THE 21 $1^{\text {st }}$ CENTURY \\
Vol. 76, No. 5, 2018 \\
\hline 615
\end{tabular} 
Sibel ER NAS, Muammer ÇALIK. A cross-age comparison of science student teachers' conceptual understanding of soil erosion

\section{PROBLEMS \\ OF EDUCATION \\ IN THE $21^{\text {st }}$ CENTURY Vol. 76, No. 5, 2018 \\ 616}

these concepts properly. Because 'soil erosion' is an interdisciplinary concept, undergraduate students from geography, social studies, earth sciences, and forestry should be encouraged to conduct cooperative learning tasks/activities about the sustainability of soil.

\section{Acknowledgements}

The authors would like to thank Professor Neil Taylor from University of New England, Australia for his kind help in language polishing.

\section{References}

Abraham, M. R., Williamson, V. M., \& Westbrook, S. L (1994). A cross-age study of the understanding of five concepts. Journal of Research in Science Teaching, 31 (2), 147-165.

Akpinar, B. (2010). Transformative learning theory: Learning by transforming and changing. Anadolu University Journal of Social Sciences, 10 (2), 185-198.

Aldrich-Moodie, B., \& Kwong, J. (1997). Environmental education. London: The IEA Education and Training Unit and the IEA Environment Unit.

Alım, M., Özdemir, Ü., \& Yılar, B. (2008). 5. sınıf öğrencilerinin bazı coğrafya kavramlarını anlama düzeyleri ve kavram yallgiların [The perceptions levels of the geography concepts and the misconception of the 5th year students]. Atatürk University Journal of Graduate School of Social Sciences, 11 (1), 151-162.

Ateş, M. (2013). A research on high school students' concepts of "erosion" by using phenomenographic analysis. Educational Research and Reviews, 8 (9), 449-453.

Ay, C., \& Ecevit, Z. (2005). Environmentally conscious consumers. Akdeniz University Faculty of Economics \& Administrative Sciences Faculty Journal, 10, 238-263.

Bağ, H., \& Çalık, M. (2017). A thematic review of argumentation studies at the K-8 level. Education and Science, 42, 281-303.

Birişçi, S., \& Metin, M. (2010). Developing an instructional material using a concept cartoon adapted to the 5E model: A sample of teaching erosion. Asia-Pacific Forum on Science Learning and Teaching, 11 (1), 1-16.

Bissonnais, Y.L., Montier, C., Jamagne, M., Daroussin, J., \& King, D. (2001). Mapping erosion risk for cultivated soil in France. Catena, 46, 207-220.

Bouaziz, M., Leidig, M., \& Gloaguen, R. (2011). Optimal parameter selection for qualitative regional erosion risk monitoring: A remote sensing study of SE Ethiopia. Geoscience Frontiers, 2 (2), 237-245.

Bozkurt, O., Salman Akın, B., \& Uşak, M. (2004). İlköğretim 6., 7, ve 8. sınıf öğrencilerinin “erozyon” kavramı hakkındaki ön bilgilerinin ve kavram yanılgılarının tespiti [Identifying of grade 6, 7 and 8 students' pre-informations and misconceptions about the erosion]. Journal of Kırşehir Education Faculty, 5 (2), 277-285.

Çalık, M. (2005). A cross-age study of different perspectives in solution chemistry from junior to senior high school. International Journal of Science and Mathematics Education, 3 (4), 671-696.

Çalik, M., \& Cobern, W.W. (2017). A cross-cultural study of CKCM efficacy in an undergraduate chemistry classroom. Chemistry Education: Research and Practice, 18, 691-709.

Çalık, M., \& Eames, C. (2012). The significance of national context: A comparison of environmental education in Turkey and New Zealand. Asia Pacific Education Researcher, 21 (3), 423-433.

Çalık, M., Ültay, N., Kolomuç, A., \& Aytar, A. (2015). A cross-age study of science student teachers' chemistry attitudes. Chemistry Education Research and Practice, 16 (2), 228-236.

Chi, M. T. H. (1992). Conceptual change within and across ontological categories examples from learning and discovery in science. In R. Giere (Ed.), Cognitive models of science: Minnesota studies in the philosophy of science (pp.129-160). Minneapolis, MN: University of Minnesota Press.

Cruden, D. M. (1991). A simple definition of a landslide. Bulletin of the International Association of Engineering Geology, 43 (1), 27-29.

Demirbaş, M., \& Pektaş, H. M. (2009). İlköğretim öğrencilerinin çevre sorunu ile ilişkili temel kavramları gerçekleştirme düzeyleri [Elementary students' levels of realization of basic concepts related with environment problem]. Necatibey Faculty of Education Electronic Journal of Science and Mathematics Education, 3 (2), 195-211. 
Demirkaya, H. (2008). The understandings of global warming and learning styles: A phenomenographic analysis of prospective primary school teachers. Educational Sciences: Theory \& Practice, 8 (1), 33- 58.

Erduran, S., \& Jiménez-Aleixandre, M. P. (2007). Argumentation in science education: Recent developments and future directions. New York, NY: Springer.

Filiz, M., \& Avc1, H. (2013). Trabzon ilinde meydana gelen heyelanlar ve heyelanların bölgeye etkileri [Landslides and their effects at the Trabzon province]. Süleyman Demirel University International Technologic Science, 5 (3), 31-38.

Franco C., \& Colinvaux D., (2000), Grasping mental models. In J. K. Gilbert, \& C. J. Boulter (Eds.), Developing models in science education (pp.93-118). Dordrecht, the Netherlands: Kluwer Academic Publishers.

Gökdere, M., \& Çalik, M. (2010). A cross-age study of Turkish students' mental models: An "atom” concept". Didactica Slovenica-Pedagoska Obzorja, 25, 185-199.

Harrison, A. G., \& Treagust, D. F. (2000). A typology of school science models. International Journal of Science Education, 22 (9), 1011-1026.

Hsu, S-J., \& Roth, R. E. (1996). An assessment of environmental knowledge and attitudes held by community leaders in the Hualien Area of Taiwan. Journal of Environmental Education, 28 (1), 24-31.

Iverson, R. M. (2000). Landslide triggering by rain infiltration. Water Resources Research, 36 (7), 1897 1910.

İyibil, Ü., \& Sağlam Arslan, A. (2010). Fizik öğretmen adaylarının yıldız kavramına dair zihinsel modelleri [Pre-service physics teachers' mental models about stars]. Necatibey Faculty of Education Electronic Journal of Science \& Mathematics Education, 4 (2), 25-46.

Jonassen, J. (2000). Towards a design theory of problem solving. Educational Technology Research and Development, 48 (4), 63-85.

Keefer, D. K. (2002). Investigating landslides caused by earthquakes - A historical review. Surveys in Geophysics, 23 (6), 473-510.

King, G., Keohane. R., \& Verba. S. (1994). Designing social inquiry: Scientific inference in qualitative research. Princeton. NJ: Princeton University Press.

Kiryak, Z., \& Çalik, M. (2018). Improving grade 7 students' conceptual understanding of water pollution via common knowledge construction model. International Journal of Science and Mathematics Education, 16 (6), 1025-1046. doi:10.1007/s10763-017-9820-8.

Kortz, K. M., \& Murray, D. P. (2009). Barriers to college students learning how rocks form. Journal of Geoscience Education, 57, 300-315.

Lal, R., \& Stewart, B.A. (1990). Soil degradation. New York: Springer-Verlag.

Malamud, B. D., Turcotte, D. L., Guzzetti, F., \& Reichenbach, P. (2004). Landslides, earthquakes, and erosion. Earth and Planetary Science Letters, 229, 45-59.

Marek, E. A. (1986). They misunderstand, but they'll pass. The Science Teacher, 53 (9), 32-35.

Martinez, P., Bannan, B., \& Kitsantas, A. (2012). Bilingual students' ideas and conceptual change about slow geomorphological changes caused by water. Journal of Geoscience Education, 60, 54-66.

Ministry of National Education, Board of Education. (2015). Knowledge of life curriculum for grades 1-3. Ankara: Head Council of Education and Morality.

Ministry of National Education (2004). Grade 5 social studies curriculum. Ankara: Head Council of Education and Morality.

Ministry of National Education (2011). Geography curriculum for grades 9-12. Ankara: Head Council of Education and Morality.

Ministry of National Education (2013). Science curricula for grades 3-8. Ankara: Head Council of Education and Morality.

Ministry of National Education (2015). Grade 5 science textbook. Ankara: Head Council of Education and Morality.

Montgomery, D. R. (2007). Soil erosion and agricultural sustainability. Proceedings of the National Academy of Sciences of the United States of America, 104 (33), 13268-13272.

Örnek, F. (2008). Models in science education: Applications of models in learning and teaching science. International Journal of Environmental \& Science Education, 3 (2), 35-45.

Özgen, N. (2012). Öğretmen adaylarının erozyon konusuna yönelik genel akademik bilgi düzeylerinin incelenmesi: Gazi üniversitesi örneği [To determine the general academic knowledge level of teacher candidates on erosion: Gazi university sample]. Dicle University Journal of Ziya Gökalp Faculty of Education, 18, 82-105. 
PROBLEMS

OF EDUCATION

IN THE $22^{\text {st }}$ CENTURY Vol. 76, No. 5, 2018

618

Özgen, N. (2013). Öğretmen adaylarının erozyon kavramına yönelik algıları: Fenomenografik bir araştırma [Perception of preservice teachers regarding the concept of erosion: A phenomenographic study]. Hacettepe University Journal of Education, 28 (2), 321-334.

Pimentel, D., \& Kounang, N. (1998). Ecology of soil erosion in ecosystems. Ecosystems, 1, 416- 426.

Pınar, A., \& Akdağ, H. (2012). Sosyal bilgiler öğretmen adaylarının iklim, rüzgar, sıcaklık, yağış, erozyon, ekoloji ve kavram haritalarını anlama düzeyi [Social studies teacher trainees' comprehension level of climate, wind, temperature, precipitation, erosion, ecology and map concepts]. Elementary Education Online, 11 (2), 530-542.

Prasannakumar, V., Vijith, H., Abinod, S., \& Geetha, N. (2012). Estimation of soil erosion risk within a small mountainous sub-watershed in Kerala, India, using Revised Universal Soil Loss Equation (RUSLE) and geo-information technology. Geoscience Frontiers, 3 (2), 209-215.

Primentel, D. (2006). Soil erosion: A food and environmental threat. Environment, Development and Sustainability, 8 (1), 119-137.

Roth, W. D., \& Mehta, J. D. (2002). The Rashomon effect combining positivist and interpretivist approaches in the analysis of contested events. Sociological Methods \& Research, 31 (2), 131173.

Russell, T., Bell, D., Longden, K., \& McGuigan, L. (1993). Rocks, soil and weather: Primary SPACE project research report. Liverpool, UK: University Press.

Şahin, N. F., Cerrah, L., Saka, A., \& Şahin, B. (2004). Yüksek öğretimde öğrenci merkezli çevre eğitimi dersine yönelik bir uygulama [A Practice for student centered ecology course in higher education]. Gazi University Journal of Gazi Educational Faculty, 24 (3), 113-128.

Sönmez, M. E., Çelik, M. A., \& Seven, M. (2013). Coğrafi bilgi sistemleri ve uzaktan algılama yardımıyla Kilis merkez ilçesinin erozyon risk alanlarının belirlenmesi [Determination of erosion risk areas using GIS and remote sensing in Kilis]. Kahramanmaraş Sütçü İmam University Journal of Social Sciences, 10 (1), 1-21.

Soran, H., Morgil, F. İ., Yücel, S., Atav, E., \& Işık, S. (2000). Biyoloji öğrencilerinin çevre konularına olan ilgilerinin araştırılması ve kimya öğrencileri ile karşılaştırılması [Investigation of the biology student interest in environmental issues and comparison with chemistry students]. Hacettepe University Journal of Education, 18, 128-139.

The American Heritage Science Dictionary (2017). Erosion in science. Retrieved from http://www. dictionary.com/browse/erosion.

Turan, İ., \& Kartal, A. (2012). İlköğretim 5. sınıf öğrencilerinin doğal afetler konusu ile ilgili kavram yanılg1lar1 [The misconcepts of the fifth-grade students on natural disasters]. Ahi Evran University Journal of Kirşehir Education Faculty, 13 (3), 67-81.

Ültay, N., \& Çalik, M. (2016). A comparison of different teaching designs of 'acids and bases' subject. Eurasia Journal of Mathematics, Science, \& Technology Education, 12, 57-86.

Uzun, N., \& Sağlam, N. (2005). Sosyo-ekonomik durumun çevre bilinci ve çevre akademik başarısı üzerindeki etkisi [Effect of socio-economic status on environmental awareness and environmental academic success]. Hacettepe University Journal of Education, 29, 194-202.

Vosniadou, S., \& Brewer, W. F. (1992). Mental models of the earth: A study of conceptual change in childhood. Cognitive Psychology, 24, 535-585.

Yılmaz, A., Morgil, İ., Aktug, P., \& Göbekli, İ. (2002). Ortaöğretim ve üniversite öğrencilerinin çevre, çevre kavramları ve sorunları konusundaki bilgileri ve öneriler [Knowledge of the secondary school and university students on the environment, environmental concepts and problems and suggestions]. Hacettepe University Journal of Education, 22, 156-162.

Zayimoğlu Öztürk, F., Bayat, S., \& Sarı, D. (2015). Öğrencilerin 4. sınıf sosyal bilgiler öğretim programındaki çevreyle ilişkili kavramları ifade etme düzeyleri [Primary school 4th grade students' expression status of concepts related to the environment in social studies curriculum]. Abant Izzet Baysal University Journal of Faculty of Education, 15, 216-230.

Received: June 05, 2018

Accepted: September 10, 2018 
Sibel ER NAS, Muammer ÇALIK. A cross-age comparison of science student teachers' conceptual understanding of soil erosion

PROBLEMS

OF EDUCATION

IN THE $21^{\text {st }}$ CENTURY

Vol. 76, No. 5, 2018

619

Sibel Er Nas

PhD, Assistant Professor of Science Education, Trabzon University, Fatih Faculty of Education, Trabzon, Turkey.

E-mail: sibelernas@hotmail.com

Website: http://aves.ktu.edu.tr/sibelernas/

Muammer Çalık

Professor of Chemistry Education, Trabzon University, Fatih Faculty of Education, Trabzon, Turkey.

E-mail: muammer38@hotmail.com

Website: http://aves.ktu.edu.tr/muammer38/ 